\title{
OSIGURANI RIZIK U ZDRAVSTVENOM OSIGURANJU U SVJETLU NOVIH OTKRIĆA GENETIKE
}

Prof. dr. sc. Nada Bodiroga-Vukobrat*

Doc. dr. sc. Loris Belanić**

\author{
UDK 369.2:575 \\ https://doi.org/10.30925/zpfsr.39.1.12 \\ Ur.: 19. siječnja 2018. \\ Pr.: 6. veljače 2018. \\ Pregledni znanstveni rad
}

\begin{abstract}
Sažetak
U radu se analizira osigurani rizik u zdravstvenom osiguranju u svjetlu novih otkrića genetike. U uvodnome dijelu rada autori analiziraju pojam i cilj personalizirane medicine te nadalje daju raščlambu važnosti personalizirane medicine za pokriće rizika u privatnom osiguranju te pitanja odnosa personalizirane medicine i individualiziranja rizika u osiguranju. Poseban dio rada predstavlja usporednopravna analiza zaštite informacija $i$ podataka $u$ njemačkome pravu, te pravu Velike Britanije i SAD. Vrši se raščlamba pozitivno pravnih rješenja i daje se kritički osvrt. Autori analiziraju hrvatska pozitivno pravna rješenja i daju prijedloge de lege ferenda, jer ova senzitivna oblast nije uređena u Republici Hrvatskoj.
\end{abstract}

Ključne riječi: osigurani rizik, genetska informacija, zdravstveno osiguranje, zaštita podataka iz genskih testova, prediktivni genski testovi, personalizirana medicina.

\section{UVOD - PERSONALIZIRANA MEDICINA I NJEZINI IZAZOVI}

\subsection{Pojam i cilj personalizirane medicine}

Personalizirana medicina (stratificirana, individualizirana) najčešće se označava s 4P (personalizirana, predikativna, preventivna i participativna).

Ona predstavlja sveobuhvatni odnos liječnik-pacijent koji je uz pomoć genskih testova $\mathrm{i}$ analize genoma pacijenata usmjeren na potpuno individualni pristup $\mathrm{u}$

* Dr. sc. Nada Bodiroga-Vukobrat, redovita profesorica u trajnom zvanju Pravnog fakulteta u Rijeci; nadab@pravri.hr.

** Dr. sc. Loris Belanić, docent Pravnog fakulteta u Rijeci; lorisb@pravri.hr.

Ovaj rad financira Hrvatska zaklada za znanost, projekt br. IP-2013-11-5709 "Perspektive očuvanja socijalne države: transformacija sustava socijalne sigurnosti za fizičke osobe u personaliziranoj medicini” te Sveučilište u Rijeci - potpore znanstvenim istraživanjima, projekt br. 13.08.1.2.03 "Socijalna sigurnost i tržišno natjecanje". 
postavljanju dijagnoze i u konačnici liječenju pacijenata. ${ }^{1}$

Nasuprot tomu, dosadašnja klasična medicina temeljila se na načelu one size for all, dok neku autori razmatraju proaktivni 4P (predikativna, preventivna, personalizirana i participativna. ${ }^{2}$

Autori Simmons, Dinan, Robinson i suradnici personaliziranu medicinu definiraju kao genomsku medicinu - individualno genomski sekvencioniranu baziranu na predikativnoj medicini. ${ }^{3}$

Stratificirana medicina predstavlja identifikaciju podgrupe pacijenata sa specifičnim (određenim) bolestima koje respondiraju s osobnim tretmanom te utvrđivanje nus - pojava tijekom liječenja. Zapravo, radi se o analizi i primjeni stratifikacije rizika glede prevencije. ${ }^{4}$

Precizna medicina fokusira se i cilja posebne personalne elemente odgovorne za osobnu (personalnu) patologiju određenog pojedinca u određenom vremenskom razdoblju (genomski i biološki čimbenici te stratifikacija uključujući stil života i okolišni utjecaj. ${ }^{5}$ Najčešće citirana definicija je ona U.S. Department of Health and Human Services, U.S. Food and Drug Administration koja navodi: “...personalizirana medicina može biti definirana kao medicinski tretman prilagođen pojedinom pacijentu, točnije tretman tailor made određenom pacijentu, za određenu bolest u određenom (točnom) momentu. ${ }^{\circ} \mathrm{U}$ personaliziranoj medicini liječenje pacijenata provodi se uz pomoć lijekova koji su posebno prilagođeni i ciljano dizajnirani za liječenje pojedinog pacijenta i to upravo korištenjem suvremenih dostignuća na području genetike. Pored navedenog, personalizirana medicina obuhvaća i poduzimanje individualiziranih genskih testova za procjenu rizika nastanka određene bolesti (tzv. prediktivni ili predviđajući testovi) te u vezi s time poduzimanje individualiziranih preventivnih mjera (npr. personalizirana stanična terapija, personalizirana terapija s lijekovima) kako bi se eventualna pojava takve bolesti spriječila. ${ }^{7}$ Konačno, personalizirana

1 BODIROGA-VUKOBRAT N., HORAK, H., Challenges of Personalized Medicine: SocioLegal Disputes and Possible Solutions, u: BODIROGA-VUKOBRAT, Nada, RUKAVINA, Daniel, PAVELIĆ, Krešimir, SANDER, G. Gerald, Personalized Medicine, A New Medical and Social Challenge, Springer International Publishing Switzerland, 2016., str. 33.

2 HOOD L., FRIEND, SH., Predictive, personalized, preventive, participatory P4 cancer medicine, Nat Rev Clin Oncol, vol. 8, br. 3., 2011, str. 184-187.

3 SIMMONS, LA, DINAN, MA, ROBINSON TJ, et al., Personalized medicine is more than genomic medicine: confusion over terminology impedes progress towards personalized health care, Pers Med, , vol. 9., br. 1., 2012., str. 85-91.

4 TRUSHEIM, MR., BERNDT, ER., DOUGLAS, FR., Stratified Medicine: strategic and economic implications of combining drugs and clinical biomarkers, Nat Rev Drug Discov, vol. 6, br. 4., 2007, str. 287-293.

5 MIRNEZAMI, R., NICHOLSON, J., DARZI, A., Preparing for precision medicine, N Engl J Med, vol. 366, br. 6, 2012., str. 489-491, također vidi National Research Council on a Framework for Developing a New Taxonomy Disease...

6 U.S. Department of Health and Human Services, U.S. Food and Drug Administration, 2013, Paving the way for personalized medicine: FDA's role in a new era of medical product development. http//www.fda.gov/downloads/ScienceResearch/SpecialTopics/ PersonalizedMedicine/UCM372421.pdf, pristupljeno, 15.10.2017.

7 NIEDERLAG, W., LERNKE, H. U., RIENHOFF, O., Personalisierte Medizin und individuelIe Gesundheitsversorgung, Bundesgesundheitsbl, vol. 53, 2010., str. 776. 
medicina obuhvaća i pitanja obrade ogromne količine podataka dobivenih genskim testiranjem (bilo prediktivnim, bilo dijagnostičkim) pacijenata, kao i zaštite tih podataka. ${ }^{8}$

Cilj je personalizirane medicine $\mathrm{s}$ jedne strane poboljšati učinkovitost medicinskih tretmana uz pomoć suvremenih dijagnostičkih postupaka, a s druge smanjiti neželjene posljedice primjene lijekova kao i troškove liječenja, uključujući i smanjenje potrošnje lijekova. ${ }^{9}$ Smanjivanjem troškova liječenja, personalizirana medicina istodobno ostvaruje pozitivan učinak na troškove zdravstva općenito.

\subsection{Izazovi novih tehnologija u personaliziranoj medicini}

S tim u vezi, nužno je na ovome mjestu samo primjerično ukazati na paralelno postojanje subjektivnog prava - pravo znati i subjektivnog prava pravo ne znati (o kojima se osobito raspravlja u genetskoj dijagnostici), pored kojih mnogobrojni objektivno-pravni propisi kao što su pravila osiguranja kvalitete te pravila postupanja s genetskim podacima zauzimaju središnje mjesto.

Često se o personaliziranoj medicini (misli i podrazumijeva) kao prediktivnoj medicini. Zapravo, ne radi se uvijek o pacijentima u smislu oboljelih osoba.

Naprotiv, osobito na području prediktivnih pregleda često nije riječ o bolesnicima, već samo o potencijalno ugroženim osobama ("nositeljima rizika") koje se u humanoj genetici ponekad naziva i klijentima. Naime, koncepti genetske individualizacije i "genetske predikcije i prevencije" utječu na pojam bolesti koji medicinski i normativno zauzima središnje mjesto.

Kada se radi o osobnim podacima važno je razlikovati je li riječ o obradi podataka oboljelih pacijenata ili o dobivanju prediktivnih zdravstvenih informacija osoba koje nisu bolesne, a koje su svakako predsimptomatične. Dakle, je li riječ o kurativnoj medicini obrade ili o prediktivnoj i preventivnoj medicini koja je orijentirana na rizik. Ovi potonji u načelu se razlikuju od obrade u klasičnom smislu kurativne medicine. U kontekstu personalizirane medicine povezani su s dalekosežnim pravnim problemima koji proizlaze iz njih. Pritom nije riječ o liječenju oboljelih osoba već o pregledavanju zdravih osoba, osoba koje nemaju nikakvih simptoma, u utvrđivanju imaju li rizičan status.

To najzornije pokazuje tablica 1. (u prilogu) gdje autor Li daje pojednostavljenu usporedbu kliničke genetike i anticipirane genomske medicine.

Rastući broj novih testova i metoda pretraga koji se temelje na biomarkerima, kao i individualizirane terapije, idućih godina ${ }^{10}$ dostići će stadij razvoja u kojem će se nalaziti na prijelazu u primjenu u zdravstvenoj skrbi, pa se individualizacija zdravstvene skrbi sa znanstveno-tehnološkog stajališta čini mogućom za 15 do 20 godina. ${ }^{11}$ Za važno područje farmakogenetike još prije nekoliko godina, uzevši u

8 BODIROGA-VUKOBRAT, N., HORAK, H., op. cit., str. 33.

9 KROEMER, H.K., Personalisierte Medizin-zum Stand derForschung, u:PersonalisierteMedizin - der Patient als NutznieBer oder Opfer, Tagungsdokumentation, Jahrestagung des Deutschen Ethikrates, 2012, str. 12.

10 Pavelić i drugi, tablica br. 2 u prilogu. 
obzir "tek pojedinačne kliničke primjene farmakogenetskih testova", isticano je kako farmakogenetika "(jest) više teoretski koncept negoli ustaljena praksa koji do sada u pravilu nije pružio dokaz kliničke relevantnosti”.

\subsection{Važnost informacija i osobnih podataka u personaliziranoj medicini}

Veliki utjecaj na personaliziranu medicinu imaju dvije tehnologije genomike; s jedne strane analiza varijacija pojedinih DNK tzv. Single Nucleotide Polymorphisms (SNP), a s druge sekvencioniranje cjelokupnoga genoma. Ako tomu dodamo pretpostavku stvaranja integrativnog personalnog omicsa (engl. integrative personal omics), jasno je kolika je i kakva količina informacija u liječničkoj ordinaciji i bazama podataka.

Za pravno razmatranje koncepta personalizirane medicine pitanje informacija kako za liječnika, i za pacijenta, a posebice za osiguravatelja je od osobite važnosti.

Važnost se ogleda u potrebnim informacijama za sve dionike za informacijama, ali posebice u subjektivnom pravu na informacije pacijenata i drugih osoba kojih se to tiče. Vezano uz prvu navedenu činjenice njemački Bundestag u svojim materijalima stoga ističe: "Osobito u pogledu individualnih usluga potrebno je polaziti od osobito izražene potrebe pogođenih osoba (osoba na koje se odnose informacije). Stratifikacija skupine pacijenata temeljem dodatnih kriterija u sve veći broj sve manjih djelomičnih populacija znatno može povećati utrošak za razvoj i provedbu informacijskih mjera. Polazeći od tradicionalnih skupina pacijenata (primjerice dijabetes tipa 2) nastala bi potreba za konceptima informiranja i savjetovanja ljudi s mnogobrojnim kombinacijama određenih rezultata testiranja". ${ }^{12}$

U sklopu razine obrade posebice se mora s osobitom pažnjom postupati vezano uz zaštitu osobnosti i uvažavanja prava osobnosti što potvrđuju slijedeći navodi: "Individualizirana medicina s tim u vezi u osobitoj je mjeri upravljena na aspekte autonomije stranaka i suverenitet konzumenata kada čini izglednim staviti pacijentima na raspolaganje više i bolje informacije o njihovom aktualnom i mogućem budućem zdravstvenom stanju nego do sada i biti u mogućnosti dati im što je moguće veći izbor sukladno njihovim preferencijama. Istodobno će se individualnom medicinom moći realizirati očekivani individualni i kolektivni zdravstveni efekti samo ako građani nisu spremni pristati na pretrage kojima se utvrđuje njihov individualni rizik obolijevanja već ako će građani biti i u stanju pretvoriti rezultat testiranja u postupanje koje je, gledano s medicinske i zdravstvenopolitičke perspektive, "smisleno" i primjereno u odnosu na zdravlje". ${ }^{13}$

Stoga ovaj Dokument snažno naglašava presumpciju: "U dogledno vrijeme će se visok stupanj otvorenosti prema mjerama individualizirane medicine, materijalni i kognitivni preduvjeti za njezinu traženost i korištenje s velikom vjerojatnošću

Gesundheitssystem, op. cit., (bilj. 2), str. 10., 111. i slj.

12 DEUTSCHERBUNDESTAG,ZukunftsreportIndividualisierte Medizin und Gesundheitssystem (bilj. 2), str. 144.

13 DEUTSCHER BUNDESTAG,ZukunftsreportIndividualisierte Medizin und Gesundheitssystem (bilj. 2), str. 12. 
moći susresti u višim socijalnim te ekonomski jačim skupinama koje time postaju i preferirana ciljna skupina odgovarajuće ponude medicinskih usluga. Za razliku od toga osobe slabog obrazovanja u socijalno zakinutim miljeima s velikom će vjerojatnosti imati poteškoće pripremiti odgovarajuće zdravstvene kompetentnosti i resurse te dobiti pristup individualiziranoj medicini dokle god $\mathrm{u}$ tome ne dobivaju pomoć u obliku mjera koje su primjerene ciljnoj skupini”. ${ }^{14}$

\section{VAŽNOSTI PERSONALIZIRANE MEDICINE ZA POKRIĆE RIZIKA U PRIVATNOM OSIGURANJU}

Glede personalizirane medicine tek se nalaze na početku i određena razmišljanja u vezi osiguravateljsko-pravnim posljedicama za pacijente. Implikacije za osiguravateljski sustav za sada još su usko ograničene. "Zbog jakog naglašavanja utvrđivanja individualnih rizika bolesti, kao i vlastite odgovornosti pacijenta u individualiziranoj medicini, postavlja se osobito pitanje kako se pri utvrđivanju iznosa premije te određivanja usluga u slučaju bolesti odnosno potrebe za njegom uzimaju u obzir odnosno trebaju uzeti u obzir individualni rizici bolesti". ${ }^{15}$

Autori Handschin i Meyer ${ }^{16}$ ukazuju glede osobe kako je važno utvrditi kako svaki medikament, kod svake bolesti djeluje kao rezultat kompleksne interakcije, genetičkih i osobnih i okolišnih čimbenika.

\begin{tabular}{|c|c|}
\hline OSOBA & OKOLIŠ / PONAŠANJE \\
\hline Dob & Ishrana \\
\hline Spol & $\begin{array}{c}\text { Lijekovi } \\
\text { (interakcija) }\end{array}$ \\
\hline Težina & $\begin{array}{c}\text { Navike, životni stil } \\
\text { (pušenje, alkohol, stres, sport), } \\
\text { kronobiološki ritam }\end{array}$ \\
\hline $\begin{array}{c}\text { Stanje zdravlja, /jetra, bubrezi, srce, upalna } \\
\text { stanja/ }\end{array}$ & Crijevna mikrobiota \\
\hline $\begin{array}{c}\text { Genom, transkripcija, proteom, epigenom } \\
\text { (monogeni - multigene varijacije) }\end{array}$ & Usklađenost \\
\hline $\begin{array}{c}\text { Genetički polimorfizmi } \\
\text { Lijekovi - metabolički enzimi i transporteri, } \\
\text { receptori, imunosni sustav }\end{array}$ & \\
\hline
\end{tabular}

Koncept personalizirane medicine temelji se na činjenici da je svaki čovjek "unikatan", jedinstven, ne samo glede sekvencioniranja genoma i epigenetskih

14 DEUTSCHERBUNDESTAG,Zukunftsreport Individualisierte Medizin und Gesundheitssystem (bilj. 2), str. 12.

15 DEUTSCHER BUNDESTAG, Zukunftsreport Individualisierte Medizin und Gesundheitssystem, op. cit., (bilj. 2), str. 14, 148.

16 HANDSCHIN, CH., MEYER URA: A, Warum reagiert mein Patient anders auf dieses Medikament?, Schweiz Med Forum, vol. 12, br. 22, 2012., str. 425-433. 
posebnosti nego i naprijed navedenih karakteristika osobe, okoliša i ponašanja.”17

U sadašnjem sustavu zdravstvenog osiguranja koji sadrži zakonska zdravstvena osiguranja temeljena na načelu solidarnosti te privatna zdravstvena osiguranja temeljena na načelu ekvivalentnosti, relevantnost ovog aspekta postoji prije svega za privatni osiguravateljski sektor za kojega točno razvrstavanje podnositelja zahtjeva odnosno osiguranika u određenu rizičnu skupinu ima veliku važnost u pogledu određivanja povišenih tarifa za rizik, ograničenja usluga ili uskraćivanje osiguranja. Stoga su postupci individualizirane medicine u načelu zanimljivi privatnom osiguravateljskom sektoru s aspekta boljeg procjenjivanja rizika obolijevanja osobe koja želi pristupiti od dosadašnjih procjena. ${ }^{18}$ Ako se osiguravateljima omogući postavljanje određenih pitanja izražene su bojazni "kako će osobe s visokim rizikom obolijevanja u većoj mjeri nego do sada

- moći sklopiti zdravstveno osiguranje samo još pod okolnostima koje su za njih vrlo nepovoljne odnosno neće uopće moći sklopiti takvo osiguranje;

- za pristup baš onim uslugama individualizirane medicine koje bi im eventualno mogle koristiti u posebnoj mjeri biti suočene $\mathrm{s}$ velikim (financijskim) preprekama;

- okupljati se u zakonskom zdravstvenom osiguranju;

- propustiti testiranje kako ne bi bile dužne osiguravatelja obavijestiti o rizicima koji su proizašli iz toga." ${ }^{19}$

U obveznom zdravstvenom osiguranju iznos doprinosa i opseg usluga ne ovise o individualnom riziku. Međutim, ovdje se postavlja pitanje mogu li opcije personalizirane medicine biti uvrštene $u$ katalog usluga i u kojoj mjeri.

Stoga njemački Bundestag u Izvještaju o budućnosti individualizirane medicine i zdravstvenog sustava (Zukunftsbericht individualisierte Medizin und Gesundheitssystem) utvrđuje: "Široko korištenje prediktivno-probalističnih zdravstvenih informacija temeljenih na biomarkerima, a kako bi se odobrile ili uskratile usluge zdravstvenog osiguranja odnosno kako bi se u odnosu na zdravlje zahtijevalo određeno ponašanje, predstavljalo bi ograničenje samoodređenja pojedinca koje se mora odvagnuti s interesima zajednice u solidarnosti. U tu svrhu potrebno je legitimirati pod kojim se okolnostima takvo ograničenje čini opravdanim te biraju li se djelotvorni i etički primjereni putevi kako bi se utjecalo na odluku pojedinca. Za takvu legitimaciju potrebno je pojedinačno razjasniti je li mjera dokazano djelotvorna te ima li povoljan omjer koristi i rizika te prihvatljiv odnos između troškova i koristi. Ovi preduvjeti za sada još nisu ispunjeni". ${ }^{20}$

17 HANDSCHIN, CH., MEYER, URA., op. cit., str. 425-433.

18 BODIROGA-VUKOBRAT, N., HORAK, H., op. cit., str. 39-40.

19 DEUTSCHER BUNDESTAG, Zukunftsreport Individualisierte Medizin und Gesundheitssystem, op. cit., (bilj. 2), str. 15., 148. BODIROGA-VUKOBRAT, Nada, HORAK, Hana, op. cit., str. 40. VOGENBERG F. R., ISAACSON BARASH C., PURSEL, M., Personalized medicine, Part 3: Challenges facing health care plans in implementing coverage polieies for pharmacogenomics and genetic testing, P T vol. 35., br. 12, 2010, str. 670-675.

20 DEUTSCHER BUNDESTAG, Zukunftsreport Individualisierte Medizin und Gesundheitssystem, op. cit., (bilj. 2), str. 15., 148., BODIROGA-VUKOBRAT, N., HORAK, 


\section{PERSONALIZIRANA MEDICINA I INDIVIDUALIZACIJA RIZIKA U OSIGURANJU}

Razvojem znanosti, personalizirana medicina moći će svakom pojedincu predvidjeti personalizirani rizik nastanka određene bolesti u jednom predvidljivom vremenskom razdoblju. ${ }^{21}$ Time ujedno dolazi do identifikacije rizika oboljenja pojedinca u medicinskom kontekstu. Posljedično navedenome, pojedinac će ujedno moći poduzeti odgovarajuće preventivne mjere i time preuzeti na sebe odgovornost za vlastito zdravlje. Činjenica je da na pojavu bolesti osim, tzv. identifikacije medicinskog rizika, utječu i faktori okoline, te razni strukturni i socijalni mehanizmi. Posljedično tomu za potpunu individualizaciju rizika i njegovu procjenu u osigurateljskom smislu osim medicinskih faktora potrebno uzeti u obzir i navedene ne - medicinske faktore. Stoga, se pri ugovaranju osigurateljskog pokrića i izačuna premije sukladno preuzetom riziku uzima u obzir i osiguranikovo (pacijentovo) ponašanje u vezi s prevencijom mogućih prediktivnih oboljenja. ${ }^{22}$

Personalizirana medicina zasigurno će otvoriti novu nišu za privatne osiguratelje zdravstvenog, ali i životnog osiguranja. Načelo da je iznos premije primjeren riziku ostvarit će svoj puni potencijal. Može se očekivati porast konkurencije među osigurateljima pa će tako visina premije i benefita iz osiguranja pridonijeti konkurentnosti i atraktivnost pojedinih osiguratelja. ${ }^{23} \mathrm{U}$ literaturi se predlažu različiti modeli povezivanja premije s individualiziranim rizikom:

- iznos premije razlikuje se u skladu s preuzetim rizikom (veći rizik, veći iznos premije);

- ako su premije osiguranja jednake, rizik i opseg pokrića iz osiguranja mogu se usklađivati isključivanjem ili uključivanjem određenih benefita iz osiguranja;

- iznosi premije mogu se kombinirati u različitim paketima pogodnosti iz osiguranja; iznos bi se izračunao u skladu s rizikom, tj. odgovarajući paket i odgovarajuće pogodnosti. ${ }^{24}$

Primjenom personalizirane medicine, bit će moguće da se pojedincima ponudi osigurateljsko pokriće u skladu s njihovim, tzv. osobnim profilom rizika, a što će u konačnici biti ništa drugo nego potvrda već prihvaćene diferencijacije rizika, prema kojoj pojedinci s većim rizikom plaćaju višu premiju, i obrnuto, pojedinci s manjim rizikom plaćaju nižu premiju. U literaturi se navodi da su čak već i u uporabi različiti instrumenti diferencijacije rizika, poput obveza prijave (npr. rezultati genskih testova), veća premija za veći rizik, odbijanje sklapanja ugovora o osiguranju s osobama koje nose određeni rizik, itd. ${ }^{25}$

H., op. cit., str. 40.

21 BODIROGA-VUKOBRAT, N., HORAK, H., op. cit., str. 41.

22 Loc. cit.

23 Loc. cit.

24 DEUTSCHER BUNDESTAG, Zukunftsreport Individualisierte Medizin und Gesundheitssystem, op. cit., str. 145.

25 FEUERSTEIN, G., KOLLEK, R., UHLEMANN, T., Gentechnik und Krankenversicherung: Neue Leistungsangebote im Gesundheitssystem. Nomos, Baden-Baden, 2002. 
Ono što neminovno proizlazi iz navedenoga, jest pod kojim uvjetima i u kojoj mjeri mogu poslužiti genetski testovi i prediktivne genetske informacije kao preduvjet za sklapanje ugovora o osiguranju. Navedeno pitanje je, stoga, potrebno zakonski urediti što prije. ${ }^{26}$ Naime, postoji opasnost od erozije načela solidarnosti, kao temeljnog načela svakog osiguranja, time što bi osiguratelji upravo zbog postojanja genetske informacije isključili iz osiguranja ili nametnuli veće obveze postojećim ili budućim osiguranicima. ${ }^{27} \mathrm{~S}$ pravom se postavlja pitanje, je li sa stajališta osiguranika svrsishodno prijavljivati genetske informacije svojim osiguranicima, i ako da, u kojem opsegu te bi li se prijavljivanje genetskih informacija odnosilo na sva vrste osiguranja, ili samo ne neke. $\mathrm{O}$ takvim i sličnim pitanjima u poredbenom zakonodavstvu već su prisutna neka konkretna rješenja, koja ćemo prikazati u nastavku rada.

\section{ZAŠTITA PODATAKA IZ GENSKIH TESTOVA U POREDBENOM PRAVU OSIGURANJA}

\subsection{Njemačko pravo}

\subsubsection{Općenito}

Temeljni propis koji uređuje pitanje zaštite podataka iz genskih testova $u$ njemačkom je pravu Zakon o genetskim ispitivanjima na ljudima ${ }^{28}$ (njem: Gesetz über genetische Untersuchungen bei Menschen, skraćeni naziv: Gendiagnostikgesetz (Zakon o genetskoj dijagnostici), dalje u tekstu: GenDG). Zakon je većim dijelom stupio na snagu 1. veljače 2010. godine, a u manjim dijelovima 1. veljače 2011. i 1. veljače 2012. godine ( $§ 27$. GenDG). Cilj je Zakona propisati pretpostavke za genetska ispitivanja na ljudima kao i pretpostavke za uporabu genetskih uzoraka i podataka s radi: a) sprječavanja diskriminacije među ljudima na temelju genetskih obilježja, b) zaštite ljudskog dostojanstva te c) zaštite prava na informativno samoodređenje (§ 1. GenDG). Zakon se temelji na sljedećim načelima: a) postupke genskih testova i genske analize obavljaju specijalizirani i posebno ovlašteni liječnici (§ 7 GenDG), b) osoba nad kojom se provode genetska istraživanja mora dati izričitu suglasnost $u$ pisanom obliku za takav postupak te se takva suglasnost u bilo kojem trenutku može i opozvati ( $(8 \mathrm{GenDG})$, c) prije davanja suglasnosti odgovorno/ovlašteno liječničko osoblje mora objasniti značenje i opseg provedbe genetskih istraživanja ( 9 GenDG), d) nakon provedenog testiranja odgovorno liječničko osoblje ima obvezu savjetovanja osobe nad kojom je provedeno genetsko ispitivanje u vezi s nalazima genetskih testova ( $\$ 10 \mathrm{GenDG})$, e) podaci genetskih testova dostupni su samo osobi nad kojom je provedena genska analiza te odgovornom liječniku, a ostalim trećim osobama samo ako postoji izričita i pisana suglasnost osobe koja je bila podvrgnuta postupku genske,

26 DAMM, R., Gendiagnostik als Gesetzgebungsprojekt. Regelungsinitiativen und Regelungsschwerpunkte, Bundesgesundheitsblatt Gesundheitsforschung Gesundhetisschutz, vol. 50, br. 2., 2007., str. 145-156.

27 BODIROGA-VUKOBRAT, N., HORAK, H., op. cit., str. 41.

28 Zakon o genskoj dijagnostici od 31. srpnja 2009. (BGBl. I S. 2529, 3672), zadnje mijenjan člankom 2. stavkom 1. Zakona od 4. studenog 2016. (BGBl. I S. 2460). 
analize tj. ispitivanju ( $\S 11 \mathrm{GenDG}), \mathrm{f})$ obveza čuvanja rezultata genskih testova na rok od deset godina, a nakon toga postoji obveza njihovog uništenja ( $\$ 12 \mathrm{GenDG}$ ) te g) obveza uništenja genskih uzoraka (materijala) nakon što su upotrijebljeni za potrebnu svrhu provedenog genskog ispitivanja (testa) ( $\$ 13$ GenDG). Navedeni se Zakon odnosi na zaštitu informacija dobivenih genskim testovima u odnosu na istraživanja u medicinske svrhe (§ 7-16 GenDG), utvrđivanja podrijetla (očinstva, majčinstva, i sl.) (§ $17 \mathrm{GenDG})$, osiguranja (§ $18 \mathrm{GenDG})$ te radnih odnosa (§ 19-22 GenDG). U nastavku rada detaljnije će se obraditi pitanje zaštite podatka iz genskih testova osiguranika u odnosu na osiguratelja.

\subsubsection{Zabrana zahtijevanja dostave podataka iz genskih testova}

Njemački Zakon o genetskoj dijagnostici posebnom odredbom u $§ 18$ uređuje pitanje genskih ispitivanja $i$ analiza u vezi sa sklapanjem ugovora o osiguranju. ${ }^{29}$ Nužno je istaknuti kako se navedena odredba odnosi na bilo koju vrstu ugovora o osiguranju, neovisno o tome radi li se o osiguranju imovine ili osiguranju osoba (uz određene iznimke o kojima se kasnije više govori) te neovisno o tomu radi li se o privatnom ili državnom osiguratelju s kojim se sklapa ugovor o osiguranju.

U spomenutoj odredbi u $\S 18$ st. 1. rečenica 1 . GenDG propisuje opću zabranu osigurateljima da im se dostave/prijave podaci o provedenim genskim testovima i istraživanjima osiguranika (postojećih ili potencijalnih/budućih osiguranika). Naime, osiguratelj ne može zahtijevati od osiguranika:

a) provođenje genskih testova (genetskih ispitivanja) ili analiza,

b) dostavu rezultata ili podataka genskih testova koji su već ranije poduzeti i

c) analizu podataka dobivenih od takvih ranije poduzetih genskih testova, odnosno propisana je zabrana prihvaćanja ili primjene rezultata i podataka dobivenih takvim genskim testovima.

Navedena zabrana korištenja podataka genskih testova osiguranika postoji za vrijeme prije sklapanja ugovora o osiguranju, ali i nakon njegova sklapanja tj. tijekom trajanja ugovora o osiguranju, odnosno osigurateljskog pokrića.

Navedenom odredbom $\S 18$ st. 1 reč. 1 . GenDG-a, osiguranik koji je sklopio ugovor o osiguranju ili ga namjerava sklopiti (tzv. budući osiguranik) oslobađa se od obveze da osiguratelju prijavljuje okolnosti (Anzeigepflicht) koje su bitne za ocjenu rizika, a tiču se genskih testova. Naime, u njemačkom pravu (a tako je i u hrvatskom), osiguranik ima obvezu da prije sklapanja ugovora o osiguranju prijavi osiguratelju sve poznate okolnosti rizika koje su bitne za odluku osiguratelja o sklapanju ugovora. Osiguratelj je čak ovlašten i sam postaviti određena pitanja osiguraniku pa je u tom slučaju osiguranik obvezan odgovoriti na ta pitanja, čime ispunjava svoju obvezu prijave okolnosti ( $§ 19$. st. 1. Zakona o ugovoru o osiguranju $)^{30}$. Također, obveza osiguranika da prijavi okolnosti proteže se i nakon sklapanja ugovora o osiguranju

29 TAUPITZ, J., PÖLZELBAUER C., Das deutsche Gendiagnostikgesetz, Arztrecht, br. 6, 2010., str. 148.

30 Njemački Zakon o ugovoru o osiguranju, (Versicherungsvertragsgesetz, skraćeno: VVG) od 23. studenog 2007. (BGB1. I S. 2631), zadnje mijenjan člankom 15. Zakona od 17. kolovoza 2017. (BGBl. I S. 3214). 
(tj. tijekom njegova trajanja), ako bi takve okolnosti utjecale na povećanje rizika (§ 23. st. 3. Zakona o ugovoru o osiguranju). Ako bi osiguranik povrijedio ovu navedenu predugovornu obvezu prijave okolnosti, osiguratelj može raskinuti, odnosno otkazati ugovor o osiguranju (§ 19. st. 2. i 3. i § 24. st. 1. i 2. Zakona o ugovoru o osiguranju). Upravo §18. st. 1. reč. 1. GenDG omogućio je osiguraniku da nije u obvezi prijavljivati osiguratelju podatke dobivene genskim testovima. S druge strane, osiguratelji nemaju pravo postavljati pitanja osiguraniku koji bi se odnosili na rezultate genskih testova, odnosno ako bi takva pitanja bila i postavljena (u bilo kojem obliku) osiguranik nije dužan odgovarati na njih. Ako osiguranik samoinicijativno dostavi podatke genskih testova, takve podatke osiguratelj ne smije uzeti u obzir. Posljedica oslobađanja osiguranika od obveze prijave podataka dobivenih genskim testovima jest da osiguratelj ne može raskinuti ugovor o osiguranju ili ga otkazati zbog neprijavljivanja okolnosti.

No, treba naglasiti da se osiguratelju sukladno zakonskim ili ugovornim obvezama moraju prijaviti sve ostale okolnosti rizika koje su bitne za donošenje odluke osiguratelja da sklopi ugovor o osiguranju s konkretnim osiguranikom, kao i okolnosti koje se tiču povećanja rizika kod već sklopljenih ugovora o osiguranju, a ne tiču se provođenja genskih testova niti prijavljivanja njihovih rezultata kao ni analize takvih rezultata. Pogotovo se ta obveza prijavljivanja okolnosti odnosi na razne bolesti i oboljenja o čijem eventualnom postojanju osiguratelj zahtijeva biti informiran ( $\$ 18$. st. 2. GenDG), a o kojima su podaci dostupni i u liječničkim kartonima pacijenta/ osiguranika i bez provođenja genskih testova. Vezano uz takve okolnosti postoji obveza njihove prijave jer u protivnom može nastupiti povreda obveze prijavljivanja iz § 19-23 Zakona o ugovoru o osiguranju, a što može imati za posljedicu nastanak prava osiguratelja na raskid, otkaz ili, čak, i poništaj ugovora o osiguranju (ovisno o okolnostima $\mathrm{i}$ ispunjenim pretpostavkama).

\subsubsection{Iznimke od zabrane zahtijevanja prijave/dostave podataka}

Zakon o genetskoj dijagnostici poznaje i jednu iznimku od načelne zabrane da osiguratelj može zahtijevati biti informiran o rezultatima poduzetih genskih ispitivanja (§ 18. st. 1. reč 2. GenDG). Pravo osiguratelja biti informiran o rezultatima genskih testova uvjetovano je kumulativnim ispunjenjem triju pretpostavki: 1.) inicijativa za poduzimanje genskih testova mora dolaziti osiguranika, 2.) vrsta osigurateljskog pokrića i 3.) visina iznosa obveze osiguranja odnosno visine svote osiguranja. Tek kad su ispunjene sve tri pretpostavke nastaje pravo osiguratelja biti informiran o rezultatima genskih testova. Ako nije ispunjena samo jedna od pretpostavki ne postoji ni pravo osiguratelja da bude informiran o rezultatima genskih testova.

U pogledu prve pretpostavke (inicijativa za poduzimanje genskih testova) osiguratelj može zahtijevati samo dostavu rezultata ili podataka genskih testova koji su ranije poduzeti (dakle, neovisno o volji osiguranika da sklopi ugovor o osiguranju), odnosno analizu podataka dobivenih od takvih ranije poduzetih genskih testova koje potom može prihvatiti ili primijeniti (a može ih i odbiti i ne primijeniti). Osiguratelj nikada ne bi mogao svojevoljno zahtijevati da se osiguranik podvrgne provođenju genskih testova (genetskih ispitivanja) ili analizi samo za potrebe procjene rizika za 
sklapanje (ili održavanje) ugovora o osiguranju. Dakle, ako je osiguranik svojevoljno odlučio i proveo genske testove na vlastitoj osobi, tada bi postojala njegova obveza da o tomu obavijesti osiguratelja (ako je genskim testiranjem utvrđeno postojanje određenog rizika za zdravlje, odnosno za razvoj određene bolesti). No s druge strane, osiguratelj ne može samostalno zahtijevati provedbu genskog testiranja osiguranika.

U pogledu pretpostavke vrste osigurateljskog pokrića pravo osiguratelja biti informiran o rezultatima genskih testova ovisi o vrsti ugovora o osiguranju koji se sklapa ili je sklopljen s osiguranikom. Navedeno pravo osiguratelja biti informiran postoji samo ako se radi: 1) o ugovoru o životnom osiguranju, 2) o ugovoru o osiguranju zbog profesionalne nesposobnosti za rad, 3) o ugovoru o osiguranju nesposobnosti za privređivanje općenito (osiguranje u slučaj invaliditeta) te 4) o ugovoru o osiguranju tuđe pomoći i njege. Dakle samo kod navedene četiri vrste ugovora o osiguranju postojalo bi pravo osiguratelja da bude informiran o rezultatima genskih testova (uz uvjet ispunjavanja ostalih pretpostavki).

I konačno, treća pretpostavka koja mora biti ispunjena za nastanak prava osiguratelja biti informiran o rezultatima genskih testova odnosi se visinu osigurane svote na koju mora biti ugovorena obveza osiguratelja. Ugovorena svota osiguranja mora biti viša od 300.000 eura (jednokratno) ili više od 30.000 eura godišnje rente.

\subsubsection{Kritika zakonskog rješenja}

Njemački osiguratelji iznijeli su niz kritika na postojeće opisano zakonsko rješenje o zaštiti podataka dobivenih genskim testovima. ${ }^{31}$ Glavna se kritika odnosi na to da zakonsko rješenje u pogledu osiguratelja ne razlikuje prediktivne genske testove (koji se poduzimaju prije pojave simptoma bolesti) i dijagnostičke genske testove (koji se poduzimaju nakon pojave simptoma bolesti a radi točne dijagnoze i eventualnog liječenja), već se koristi skupni naziv "genski testovi". ${ }^{32}$ Od tuda proizlazi da osiguratelji ne mogu zahtijevati prijavljivanje podataka od osiguranika ni u pogledu prediktivnih ni u pogledu dijagnostičkih genskih testova. Osiguratelji smatraju da bi se trebalo omogućiti dostavljanje podataka o provedenim dijagnostičkim (ne i prediktivnim) genskim testovima. Ukoliko se takva obveza ne bi ispoštovala, osiguratelj bi imao pravo na raskid, odnosno otkaz ugovora zbog povrede obveze prijavljivanja ( $19-24$ VVG). Ovo stajalište osiguratelji pravdaju time što o rezultatima pojedinih dijagnostičkih genskih testova ovisi i daljnja terapija (lijekovima i druga), a troškove takve terapije osiguratelj može podmiriti samo ako je upoznat s nalazima takvih dijagnostičkih genskih testova (specifičnost za privatne osiguratelje zdravstvenog osiguranja). Od ostalih kritika koje su uputili osiguratelji, je da zabrana prijave podataka o genskim testovima narušava slobodu ugovaranja, te da ona može dovesti do povećanja premije (jer bi medicinske usluge više koristili oni osiguranici

31 Kritike dostupne u: Stellungnahme zum Entwurf eines Gesetzes über die genetische Untersuchungen bei Menschen (Gendiagnostikgesetz - GenDG) vom, 13. Oktober 2008., datum: 14. Januar 2009., Verband der Privaten Krankenversicherung e.V. [Mišljenje o Nacrtu Zakona o genskoj dijagnostici, od 13.10.2008., s datumom od 14. siječnja 2009., Udruga privatnih zdravstvenih osiguratelja]. Dalje u tekstu: Mišljenje.

32 Mišljenje, str. 5-6. 
koji su upoznati s rezultatima genskih testova, a povećanja potražnje za medicinskim uslugama može se podmiriti jedino povećanjem premije), te da zakonsko rješenje negira temeljno načelo osiguranja, a to je da se ne može osigurati rizik koji se već ostvario (npr. osiguranik se odlučuje na ugovaranje osigurateljskog pokrića nakon što je saznao rezultate genskih testova da kod njega postoji opasnost od razvoja određene bolesti). ${ }^{33}$

\subsection{Pravo Velike Britanije}

U Velikoj Britaniji ne postoji zakonski propis koji bi pružao zaštitu osiguranicima u pogledu prijavljivanja rezultata genskih testova osigurateljima (kao što je to u njemačkom pravu). Međutim, Vlada Velike Britanije i Udruga osiguratelja Britanije donijeli su zajednički dokument, koji je sporazumnoga karaktera, pod nazivom Konkordat i moratorij o genetici i osiguranju (Concordat and Moratorium on Genetics and Insurance). ${ }^{34}$ Ovaj dokument donesen je još 2001., godine, ali je revidiran nekoliko puta, posljednji put 2014. godine. Taj Konkordat na dobrovoljnoj osnovi primjenjuju britanski privatni osiguratelji zdravstvenog i životnog osiguranja pri ugovaranju pokrića s osiguranicima, a u primjeni je do 1. studenog 2019. (točka $2 b$ Konkordata), što ne isključuje mogućnost da se njegova primjena produlji i za još neko određeno vrijeme.

Osnovna svrha navedenoga dokumenta je da se osiguranicima omogući sklapanje ugovora o osiguranju (posebice ugovora životnog osiguranja i ugovora zdravstvenog osiguranja), a bez da osigurateljima prijavljuju rezultate prediktivnih genskih testova (točka 8.1. Konkordata). S druge strane, svrha Konkordata je i da se osigurateljima omogući pristup svim relevantnim informacijama kako bi mogli pravično procijeniti rizik i premiju osiguranja u korist svih osiguranika (toč. 6. i 8.2. Konkordata). Izričito je naglašeno da se moratorij odnosi samo na prijavljivanje rezultata prediktivnih testova, a ne postoji moratorij na prijavu nalaza dijagnostičkih $\mathrm{i}$ negenetskih medicinskih testova (toč. 16. Konkordata). Drugim riječima, osiguranici nisu obvezni dostavljati podatke o prediktivnim genskim testovima, ali postoji obveza prijave svih ostalih okolnosti njihova zdravstvenog stanja kada informacije o tomu zahtijeva osiguratelj. To se posebno odnosi na tzv. dijagnostičke genske testove. Ako osiguranik ne bi postupio po zahtjevu osiguratelja, počinio bi povredu obveze prijavljivanja okolnosti koje su bitne za ocjenu rizika, a što se u konačnici može smatrati i prijevarnim ponašanjem koje dovodi do prijevremenog prestanka ili čak i do poništenja ugovora o osiguranju.

Upravo zbog važnosti razlikovanja prediktivnih genskih testova i dijagnostičih genskih testova, u Konkordatu su u Aneksu 2. navedene i njihove definicije. Prediktivni genski testovi su oni koju se poduzimaju prije pojave bilo kojih simptoma, znakova ili abnormalnih rezultata negenetskih medicinskih testova, a kako bi se utvrdile pogreške u genima koje mogu biti u vezi s pojavom određenih bolesti. Upravo u pogledu

33 Mišljenje, str. 4.

34 Dostupno na: https:/www.gov.uk/government/uploads/system/uploads/attachment_data/ file/390174/Genetics_and_Insurance_guidance_2014.pdf (2. siječnja 2018.). 
rezultata takvih testova postoji dogovor britanskih osiguratelja da se oni ne trebaju prijavljivati pri ugovaranju životnog ili privatnoga zdravstvenog osiguranja. S druge strane, dijagnostički genski testovi poduzimaju se nakon pojave simptoma, znakova bolesti ili abnormalnih nalaza negenskih medicinskih testova kako bi se potvrdila (ili postavila) dijagnoza bolesti ili u slučaju sumnje na određenu bolest. Podaci dobiveni dijagnostičkim genskim testovima podliježu obvezi prijavljivanja osigurateljima, tj. na njih se ne odnosi moratorij iz Konkordata.

Osiguratelji se obvezuju da od osiguranika neće zahtijevati poduzimanje prediktivnih testova prije ugovaranja (toč. 21a Konkordata), kao i nakon ugovaranja osigurateljskog pokrića sve dok ono traje (toč. $21 \mathrm{c}$. i.) te da neće tražiti rezultate prediktivnih genskih testova od drugih osoba, poput krvnih srodnika (toč. 21c. ii).

U Konkordatu su predviđeni i slučajevi kada su osiguranici obvezni prijaviti osigurateljima rezultate prediktivnih genskih testova (toč. 26. st. I. Konkordata). Pretpostavke za to odnose se na pojedine vrste osiguranja i određenu visinu osigurane svote (slično kao i u njemačkom pravu): 1) ako osiguranik sklapa ugovor o osiguranju života s osiguranom svotom iznad 500.000 funti, 2) ako osiguranik ugovara pokriće teško bolesnih stanja (engl. critical illnes insurance) sa osiguranom svotom iznad 300.000 funti, ili 3) ako je osiguranik ugovorio osiguranje prihoda (engl. income protection insurance) sa godišnjom rentom iznad 30.000 funti. Bitno je naglasiti da je Konkordatom predviđeno da se mogu koristiti samo oni prediktivni testovi koje je odobrila Vlada i to nakon prosudbe stručnjaka (eksperata) (toč. 35. Konkordata). Do sada je Vlada odobrila samo prediktivne testove za Huntingtonovu bolest, pa je Konkordatom predviđeno da se takav test može poduzeti pri sklapanju ugovora o osiguranju života za osigurani iznos viši od 500.000 funti (toč. 21d. ii Konkordata).

Ono što je nužno naglasiti jest, da se Konkordat odnosi na poslovanje privatnih osiguratelja. Državni osiguratelj zdravstvenog osiguranja u Velikoj Britanji, National Health Service (NHS), nije njime vezan, te pruža usluge iz pokrića zdravstvenog osiguranja svim građanima, bez obzira na rezultate genskih testova pritom ne praveći diskriminaciju u snošenju troškova osiguranja.

\subsection{Pravo $S A D-a$}

U SAD-u je 2008. godine donesen Zakon o zabrani diskriminacije na temelju genetskih informacija u pogledu zdravstvenog osiguranja i zapošljavanja (The Genetic Information Nondiscrimination Act, skraćeno: GINA) ${ }^{35}$ Zakonom se nastoji zabraniti poslodavcima i osigurateljima zdravstvenog osiguranja da diskriminiraju pojedince na temelju njihove genetske predispozicije za razvijanjem bolesti. Cilj je Zakona promoviranje genetskog testiranja među što širom populacijom i stvaranje povjerenje potrošača u takve genske testove, bez straha da se podaci koji su prikupljeni na taj način iskoriste protiv njih samih. ${ }^{36}$

35 The Genetic Information Nondiscrimination Act of 2008, Pub. L. 110-233, 122 Stat. 881, od 21. svibnja 2008. Pun naziv zakona je: An Act to prohibit discrimination on the basis of genetic information with respect to health insurance and employment. 
Prema tom Zakonu, osigurateljima je zabranjena uporaba, tzv. genetskih informacija pri donošenju odluke o sklapanju ugovora o zdravstvenom osiguranju, kao i pri određivanju premije za individualno pokriće/policu osiguranja (čl. 101., st. a3, čl. 102. st.a3, čl. 103., a3, čl. 104 st. aE, čl. 2753. st. a1 i b1). Zabrana uporabe genetskih informacija tiču se samog osiguranika, ali i člana njegove obitelji. Dakle, genetska informacija, koja je dobivena na temelju genskih testova ne može se koristiti za donošenje odluke osiguratelja zdravstvenog osiguranja, hoće li, ili ne, sklopiti ugovor o osiguranju/pružiti osigurateljsko pokriće (s pojedinom osobom ili članom njegove obitelji) i s kojom premijom.

Međutim, Zakonom je izričito naglašeno da takva načelna zabrana uporabe genetskih informacija nikako ne znači da osiguratelji ne mogu odlučivati, hoće li ili ne, sklopiti ugovor o zdravstvenom osiguranju s određenom osobom i s kojom premijom ako je došlo od pojave bolesti ili do nekoga zdravstvenog poremećaja kod osiguranika ili člana njegove obitelji (čl. 2753. st. a2 i b2). No, pritom se izričito naglašava da se pojava bolesti ili poremećaja kod člana obitelji ne može smatrati kao genetskom informacijom u odlučivanju o pružanju osigurateljskog pokrića drugom članu obitelji (kao ni o visini premije). Dakle, osiguratelj može redefinirati premiju i odlučiti pod kojim će uvjetima pružati osigurateljsko prokiće osobi kod koje se bolest već manifestirala te se takvo "drukčije" ponašanje osiguratelja ne može smatrati diskriminacijom. Diskriminacija bi bila kada bi osiguratelj zbog bolesti člana obitelji odlučio pružati osigurateljsko pokriće pod drukčijim uvjetima ostalim članovima obitelji, nego što bi pružao pokriće da takva bolest ne postoji.

Zakon nadalje zabranjuje osiguratelju zdravstvenog osiguranja da od osiguranika ili člana njegove obitelji zahtjeva podvrgavanje genskim testovima, ili informiranje o rezultatima takvih testova. Istodobno se naglašava kako to nipošto ne znači da profesionalni pružatelj zdravstvenih usluga (npr. bolnice) ne mogu zahtijevati od pojedinaca podvrgavanje genskim testovima (čl. 101., st. c1 i c2, čl. 102. st. c1 i c2, čl. 103. st. c1 i c2, čl. 2753. st. d1 i d2).

Zakon posebno zabranjuje da osiguratelji prikupljaju genske podatke na bilo koji način, uključujući i kupovanje takvih podataka, a koji se tiču njihovih osiguranika (sadašnjih ili budućih) (čl. 101. st. c1 i c2, čl. 102. st. d1 i d2, 103. st. d1 i d2 čl. 2753. st. e1 i e2).

Nužno je istaknuti da se navedeni Zakon ne primjenjuje na životna osiguranja kao ni na invalidska osiguranja i osiguranja dugotrajne njege. Odatle se može zaključiti da $\mathrm{u}$ potonjim vrstama osiguranja osiguratelji mogu zahtijevati podatke nalazima genskih testova osiguranika (ili članovima njihove obitelji). ${ }^{37}$

37 ZHENG, S., The Loopholes in the Law Prohibiting Genetic Discrimination, https://www. theatlantic.com/health/archive/2017/03/genetic-discrimination-law-gina/519216/ (4. siječnja 2018.). 


\section{HRVATSKO PRAVO OSIGURANJA I GENETIČKE INFORMACIJE OSIGURANIKA - DE LEGE LATA I PRIJEDLOZI DE LEGE FERENDA}

Činjenica je da u hrvatskom pravnom sustavu ne postoji poseban propis po uzoru na prikazane poredbene sustave, a koji se odnosi na zabranu ili ograničenje pružanja genetskih podataka osiguranika privatnim osigurateljima općenito, pa tako ni osigurateljima životnog i zdravstvenog osiguranja. Drugim riječima, u sadašnjoj situaciji osiguratelji načelno nisu spriječeni da potražuju i podatke o rezultatima genskih testova osiguranika. Drugo je pitanje koliko je to izvedivo s obzirom na trenutačnu dostupnost takvih testova prosječnom hrvatskom osiguraniku, kao i na situaciju da se ne baš veliki broj ljudi odlučuje na ugovaranje životnih ili dobrovoljnih zdravstvenih osiguranja. Ovakva praksa sigurno bi još dodatno umanjila interes za takva pokrića. No, s vremenom sigurno će se postaviti i pitanje rezultata genskih testova pred hrvatske osiguratelje, te bi bilo dobro da u tom slučaju imamo već određena zakonska rješenja po pitanju dostupnosti genetičkih informacija osigurateljima.

Što se tiče sadašnje situacije, kako bi se olakšalo ispunjenje obveze prijave okolnosti važnih za ocjenu rizika, osiguratelji zdravstvenog i životnog osiguranja u praksi, prije sklapanja ugovora zahtijevaju da osiguranik ispuni upitnik o zdravstvenom stanju ili da se pripremi liječničko izvješće po izvršenom liječničkom pregledu osiguranika. Svrha navedenog upitnika i liječničkog izvješća (po obavljenom pregledu) jest omogućiti osiguratelju pravilnu ocjenu rizika budućeg osiguranika. ${ }^{38}$ No, važno je naglasiti da je neovisno o ispunjenom upitniku i liječničkom izvješću, ugovaratelj osiguranja u obvezi prijaviti sve činjenice bitne za ocjenu rizika (zdravstvenog stanja) osiguranika koje su mu poznate, odnosno nisu mu mogle ostati nepoznate (čl. 931. $\mathrm{ZOO}){ }^{39} \mathrm{U}$ tom slučaju, pitanja o činjenicama koje mu nisu postavljene u upitniku, a koje su važne za ocjenu rizika, tj. zdravstvenog stanja osiguranika, mogu imati za posljedicu primjenu pravila o netočnosti prijave ako ih ugovaratelj osiguranja nije prijavio ili ih je prešutio (namjerno ili nenamjerno) (čl. 932. i 933. ZOO). Prigovor koji se može uputiti takvom shvaćanju jest da ugovaratelj osiguranja nije stručnjak da bi mogao znati koje su okolnosti bitne za ocjenu zdravstvenog stanja osiguranika. Tomu bi se moglo doskočiti time da su upitnici što detaljniji, precizniji i jasniji. ${ }^{40}$ Time bi se ugovaratelju osiguranja/osiguraniku omogućilo da pri ispunjavanju upitnika duboko razmisli i prisjeti se eventualno još nekih okolnosti o svojem zdravstvenom stanju. S druge strane, do promjene rizika može doći i tijekom trajanja ugovora o osiguranju, a o čemu bi osiguratelj trebao znati. Informiranost osiguratelja u tom slučaju može se osigurati na način da se od osiguranika zahtijeva dostavljanje podataka o zdravstvenom stanju, pa čak i da sam provjeri zdravstveno stanje ili uzrok smrti. To znači da bi osiguratelj imao pravo uvida u liječnika izvješća, nalaze, zdravstvene kartone, pa čak da i sam osiguratelj naloži provedbu medicinskih istraga i testova (ne treba isključiti

38 ĆURKOVIĆ, M., Ugovor o osiguranju osoba, život-nezgoda-zdravstveno, Inženjerski biro, Zagreb, 2009, str. 217.

39 Zakon o obveznim odnosima, Narodne novine, br. 35/05, 41/08, 125/11 i 78/15.

40 PAK, J., Pravo osiguranja, Univerzitet Singidunum, Beograd, 2011., str. 330. 
ni provedbu genskih testova) radi što potpunijeg utvrđivanja stanja. ${ }^{41}$

Što se tiče de lege ferenda, valjalo bi po uzoru na analizirana poredbenopravna rješenja postaviti određena ograničenja po pitanju dostupnosti genetičkih podataka osiguranika njihovim osigurateljima. U tom smislu, prijedlog bi išao za time da se uvede načelna zabrana osigurateljima da od osiguranika (ali i od njihovih srodnika) zahtijevaju rezultate genskih testova kao uvjet za sklapanje ugovora o osiguranju, odnosno da takve rezultate zahtijevaju nakon sklapanja ugovora o osiguranju, a tijekom njegova trajanja. Zabrana bi se odnosila i na rezultate genetskih testova koji su osiguranici proveli na sebi i neovisno o njihovoj (budućoj) namjeri za sklapanjem ugovora osiguranju. Takvo načelno pravilo prisutno je u svim analiziranim poredbenim sustavima. Svakako bi trebalo uvažiti pravilo koje je prisutno u pravu SAD-a, da se pojava bolesti kod jednog člana obitelji ne može smatrati genetskom informacijom, no da se nikako ne može zabraniti osiguratelju da odlučuje o osigurateljskom pokriću i visini premije na temelju podataka iz zdravstvenog kartona osiguranika i obiteljske anamneze. Također, nužno je propisati i apsolutnu zabranu da osiguratelju prikupljaju genetičke podatke o osiguraniku na bilo koji način uključujući i njihovo kupovanje. Potom, valjalo bi postaviti određene iznimke od navedene opće zabrane, te propisati slučajeve kada bi osiguratelji bili ovlašteni zahtijevati podatke o provedenim genskim testovima. Tu su moguća raznovrsna rješenja: 1.) da osigurateljima budu dostupni na njihov zahtjev rezultati samo dijagnostičkih genskih testova (ne i prediktivnih), kao što je to u Velikoj Britaniji, 2.) da se propiše vrsta osigurateljskog pokrića pri čijem sklapanju bi osiguranik bio u obvezi prijaviti rezultate genskih testova, kao što su to dugogodišnja osiguranja tuđe pomoći i njege, osiguranja od teških bolesti, osiguranje od gubitka prihoda i slično (rješenje prisutno u Velikoj Britaniji i Njemačkoj), 3.) da se zakonski izričito navedu bolesti glede kojih se mogu zahtijevati genski testovi, kao što je to slučaj s Huntigtonovom bolesti u Velikoj Britaniji, 4.) da se propiše visina osigurane svote iznad kojeg iznosa osiguratelji mogu zahtijevati prethodno provođenje genskih testova, kao uvjet za sklapanje ugovora o osiguranju (npr. kao u Njemačkoj za osigurane svote više od 300.000 eura, odnosno 30.000 eura godišnje rente), 5.) moguća je i kombinacija neka od navedenih ograničenja, primjerice kombinacija visine osigurane svote i vrste osigurateljskog pokrića, 6.) da se, po uzoru na rješenje iz Velike Britanije, mogu koristiti samo oni genski testovi koje je nadležno državo tijelo odobrilo, a ne bilo koji test slobodan na tržištu, 7.) da se zabrana prikupljanja genetičkih podataka od osiguranika ne odnosi na zabranu bolnicama i ostalim pružateljima zdravstvenih usluga da provedu genetska ispitivanja pojedinaca u svrhu liječenja (kao što je to izrijekom predviđeno u pravu SAD-a).

$\mathrm{Na}$ kraju nužno je naglasiti da se u analiziranim pravnim sustavima pitanje genetskih informacija osiguranika postavlja samo u odnosu na privatne osiguratelje. Državni osiguratelji zdravstvenog osiguranja (a i mirovinskog) u pravu Velike Britanije i Njemačke ne mogu ni u kojem slučaju (za sada) praviti diskriminaciju među osiguranicima s obzirom na njihove genetske predispozicije za razvoj pojedinih

41 SLAVNIĆ, J., Ugovor o dobrovoljnom zdravstvenom osiguranju kao predmet zakonskog regulisanja - prilog raspravi o regulisanju ugovora o osiguranju u novom Građanskom zakoniku Srbije, Zbornik radova “Evropske (EU) reforme u pravu osiguranja Srbije”, Palić, 2010., str. 27. 
bolesti. Svakako bi takvo načelo o zabrani diskriminacije na temelju genetskih informacija u državnom zdravstvenom/mirovinskom osiguranju trebalo postojati i u hrvatskom pravnom sustavu neovisno o izazovima suvremene genske tehnologije.

\section{ZAKLJUČAK}

Razvoj znanosti na području genetike kao sve šira dostupnost naprednih genskih tehnologija, kao što su to prediktivni genski testovi, omogućava da se za svakog pojedinca stvori, tzv. osobni profil rizika od oboljenja pojedinih bolesti. Dodatna važnost podataka dobivenih genskim testovima ogleda se u tomu da testirana osoba poduzme određene preventivne mjere kako bi se rizik nastanka bolesti što je moguće smanjio, odnosno ako se bolest pojavi, da su njezine posljedice što moguće manje. Ujedno se naprednim genskim tehnologijama koje su usmjerene na svakog pacijenta osobno pokušava odrediti individualna terapija za liječenje postojećih bolesti. Navedeni osobni pristup u liječenju bolesti, koji je prilagođen biološkim potrebama i osobnim karakteristikama svakog pacijenta (životni stil, okolina, dob, spol, težina, navike, ishrana) uz primjenu suvremenih otkrića na području genetike temeljna je postavka, tzv. personalizirane medicine koja se temelji na konceptu da je svaki čovjek/ pacijent različita individua, unikatan i jedinstveni te da se u prevenciji i liječenju bolesti treba pristupiti maksimalno individualno.

Dakle, personalizirana medicina omogućila je da se rizik nastanka neke bolesti maksimalno individualizira, što može biti od interesa privatnim osiguravateljima zdravstvenih, ali i životnih osiguranja (životno i mirovinsko osiguranje), s obzirom na to da premija osiguranja predstavlja cijenu rizika. To bi u konačnici trebalo dovesti do diferencijacije rizika da pojedinci s većim rizikom plaćaju višu premiju, i obrnuto da pojedinci s manjim rizikom plaćaju nižu premiju, kao i do toga da pojedinci (zbog visokog rizika oboljenja kojeg nose u sebi) neće biti u mogućnosti sklopiti ugovor o osiguranju (tzv. isključenje iz osiguranja). No, ovakav pristup u primjeni rezultata genskih tehnologija pri individualizaciji rizika osiguranja vodi prema napuštanju ili bar redukciji načela solidarnosti u fondovima osiguranja iz kojih se isplaćuje naknada/osigurnina osiguranicima (svi za jednog, jedan za sve!), a u korist prevage načela ekvivalencije (svakome prema njegovom riziku!). To u konačnici može dovesti do toga da pojedincima privatno osiguranje (dobrovoljno zdravstveno, životno osiguranje, dobrovoljno mirovinsko osiguranje) bude potpuno nedostupno, odnosno da budu diskriminirani u odnosu na ostale osiguranike kojima su "geni bili blagonakloni”.

Opisani problem diskriminacije osiguranika na temelju genskih obilježja/ podataka dobivenih iz genskih testova, inozemni zakonodavci prepoznali su već odavno (unazad 10-15 godina) te su postavili određena ograničenja i zabrane u pogledu zaštite osobnih podataka osiguranika iz genskih testova. Gotovo aklamacijski, u svim analiziranim sustavima prihvaćenoje pravilo načelne zabrane zahtijevanjai dostavljanja podataka prediktivnih genskih testova osiguranika svojim osigurateljima, kao i načelo oslobađanja osiguranika od obveze prijave podataka dobivenih prediktivnim genskim testovima, kao okolnostima koje su bitne za ocjenu rizika. Od navedenih načelnih 
zabrana, ovisno o državama, postoje određena odstupanja koja se odnose na npr.: vrstu osiguranog rizika, određenu bolest, iznos svote osiguranja iznad određene granice, dostupnost podataka, tzv. dijagnostičkih genskih testova i sl. Navedenim načelnim zabranama osigurateljima da uvjetuju sklapanje ili produživanje ugovora o osiguranju provođenjem genskih ispitivanja svojih osiguranika i dostavom podataka dobivenim od tih testova, inozemni zakonodavci imaju za cilj spriječiti nejednako postupanje prema osiguranicima zbog svog naslijeđenog ili stečenoga genetskog obilježja koji predstavlja ili bi mogao predstavljati povećan rizik za nastanak bolesti. No, navedene zabrane ne sprječavaju osiguratelje da od svojih osiguranika zahtijevaju druge podatke koji također mogu poslužiti za individualizaciju rizika, kao što su to npr. podaci o osobnim karakteristikama pojedinca, povijesti bolesti, obiteljskoj anamnezi i sl.

U pogledu hrvatskoga prava, ističemo kako osiguratelji zakonski nisu spriječeni tražiti prijavu podataka dobivenih iz genskih testova, jer još ne postoji zakonski propis (po uzoru na poredbeno pravo) koji bi osigurateljima priječio prikupljanje takvih podataka od osiguranika. S obzirom na značenje takvih podataka i činjenice da prikupljanje takvih podataka može dovesti do diskriminacije osiguranika, ali općenito i do diskriminacije osobe koja se podvrgava takvim testovima neovisno i izvan potreba osiguranja, zaključujemo kako u Hrvatskoj postoji hitna potreba da se donese propis koji bi na cjelovit način uređivao pitanje zaštite podataka dobivenih od genskih testova na ljudima, kao što je to primjer u njemačkom zakonodavstvu o kojem je ranije bilo riječi. 


\section{PRILOZI}

Tablica 1: Pojednostavljena usporedba kliničke genetike i anticipirane genomske medicine $^{42}$

\begin{tabular}{|c|c|c|}
\hline & Klinička genetika & Genomska medicina \\
\hline Naglasak na & Rijetke ili vrlo rijetke bolesti & Uobičajne teške bolesti \\
\hline $\begin{array}{l}\text { Geni koji su } \\
\text { uključeni }\end{array}$ & Monogeni ili oligogeni & Često nepoznati geni \\
\hline Genske promjene & $\begin{array}{l}\text { Kromosonsko pregađivanje, } \\
\text { aneuplodije, kopiranje dupliciranje } \\
\text { i brisanje kromosona }\end{array}$ & Višestruke varijante/polimorfizmi \\
\hline Pojavnost & Visoka & Niska \\
\hline Otkrivanje bolesti & $\begin{array}{l}\text { Dijagnostika, ispitivanje nosača i } \\
\text { presimptomatsko testiranje }\end{array}$ & Prediktivna procjena rizika oboljenja \\
\hline $\begin{array}{l}\text { Presimptomatsko } \\
\text { testiranje }\end{array}$ & Visoka prediktivna vrijednost & $\begin{array}{l}\text { Niska prediktivna vrijednsot (nije još } \\
\text { dokazano) }\end{array}$ \\
\hline Liječenje & Različiti pristupi & $\begin{array}{l}\text { Personalizirani pristup koji se temelji } \\
\text { na genetskim informacijama }\end{array}$ \\
\hline Klinički genetičari & Doktor medicine, specijalist & Minimalna edukacija i praksa \\
\hline $\begin{array}{l}\text { Laboratorijski } \\
\text { genetičari }\end{array}$ & $\begin{array}{l}\text { Uglavnom doktori znanosti, dobro } \\
\text { obrazovani i osposobljeni, nadziru } \\
\text { kliničke laboratorije }\end{array}$ & $\begin{array}{l}\text { Uglavnom istraživači na doktoratima } \\
\text { bez izravne veze s kliničkom praksom }\end{array}$ \\
\hline
\end{tabular}

42 Izvor: Li, Chumei, Clinical Genetics, vol. 79, br. 5, 2011., str. 403-412. 
Tablica 2.: Projekcija tehnoloških, medicinskih i integracijskih razmatranja za primjenu personalizirane medicine. ${ }^{43}$

\begin{tabular}{|c|c|c|c|}
\hline Projekcija za & 5 godina & 10 godina & 20 godina \\
\hline \multirow{5}{*}{ Tehnologija } & Linearna tehnologija & $\begin{array}{l}\text { Izgradnja interaktivnih } \\
\text { mreža }\end{array}$ & $\begin{array}{l}\text { Mjerenje dinamične } \\
\text { mreže in vivo }\end{array}$ \\
\hline & $\begin{array}{l}\text { Genomika } \\
\text { Transkriptomika } \\
\text { Metabolomika }\end{array}$ & Molekularna interakcija & $\begin{array}{l}\text { Nadgledanje u realnom } \\
\text { vremenu }\end{array}$ \\
\hline & Nadgledanje okoline & Interakcija geni-okolina & Daljinsko očitavanje \\
\hline & & Ljudski resursi & $\begin{array}{l}\text { Mehanizmi za } \\
\text { uzbunjivanje }\end{array}$ \\
\hline & & & $\begin{array}{l}\text { Korisničko sučelje za } \\
\text { odgovor }\end{array}$ \\
\hline \multirow{7}{*}{ Medicina } & Načelo dokazivanja & Uvod & $\begin{array}{l}\text { Implementacija i } \\
\text { pročišćivanje }\end{array}$ \\
\hline & $\begin{array}{l}\text { Dostupna ciljna } \\
\text { tehnologija na jedno } \\
\text { područje bolesti }\end{array}$ & $\begin{array}{l}\text { Kumulativni podaci prema } \\
\text { osobi }\end{array}$ & $\begin{array}{l}\text { Integracija slikovnih } \\
\text { tehnologija i } \\
\text { psihološkog nadgledanja }\end{array}$ \\
\hline & $\begin{array}{l}\text { Identifikacija dostupnih } \\
\text { resursa (elektronski } \\
\text { zdravstveni zapisi, itd) }\end{array}$ & $\begin{array}{l}\text { Dinamična kvalitativna/ } \\
\text { kvantitativna mjerenja }\end{array}$ & $\begin{array}{l}\text { In silico model za } \\
\text { individualne pacijente }\end{array}$ \\
\hline & $\begin{array}{l}\text { Poboljšanje biobanki i } \\
\text { kliničko uzimanje uzoraka }\end{array}$ & $\begin{array}{l}\text { Sinergijski output } \\
\text { višestrukih markera }\end{array}$ & $\begin{array}{l}\text { Nadgledanje } \mathrm{u} \\
\text { realnom vremenu } \\
\text { (nanomaterijali) }\end{array}$ \\
\hline & $\begin{array}{l}\text { Proširene mjere za zdrave } \\
\text { pojedince }\end{array}$ & $\begin{array}{l}\text { ICT infrastruktura } \\
\text { za podršku isporuke } \\
\text { zdravstvene skrbi u } \\
\text { realnom vremenu na širem } \\
\text { teritoriju }\end{array}$ & $\begin{array}{l}\text { Udaljeno nadgledanje/ } \\
\text { Personalizirana } \\
\text { telemedicina }\end{array}$ \\
\hline & & $\begin{array}{l}\text { Sakupljanje i dijeljenje } \\
\text { neinvazivnih informacija }\end{array}$ & \\
\hline & & $\begin{array}{l}\text { Povećana preciznost } \\
\text { slikovnih tehnologija i } \\
\text { terapije }\end{array}$ & \\
\hline \multirow{7}{*}{ Integracija } & \begin{tabular}{|l|} 
Otkrića \\
\end{tabular} & Potvrđivanje & Implementacija \\
\hline & Jezgrene tehnologije & Definicija svrhe & Nanotehnologija \\
\hline & Epigenetika & Dostižni ciljevi & Uzdužni podaci \\
\hline & Prototip model & Testiranje infrastrukture & $\begin{array}{l}\text { Sistemsko sakupljanje } \\
\text { podataka }\end{array}$ \\
\hline & & & Provedba standarada \\
\hline & & & Dijeljenje podataka \\
\hline & & & E-učenje \\
\hline
\end{tabular}

43 Izvor: PAVELIĆ, K., KRALJEVIĆ PAVELIĆ, S., SEDIĆ, M., Personalized Medicine: The Path to New Medicine, Personalized Medicine - A New Medical and Social Challenge, BODIROGAVUKOBRAT, N., RUKAVINA, D., PAVELIĆ, K., SANDER, G. G., (ed.), Springer, 2016., str. 15. 


\section{LITERATURA}

1. BODIROGA-VUKOBRAT N., HORAK, H., Challenges of Personalized Medicine: Socio-Legal Disputes and Possible Solutions, u: BODIROGA-VUKOBRAT, N., RUKAVINA, D., PAVEliĆ, K., SANDER, G. G., Personalized Medicine, A New Medical and Social Challenge, Springer International Publishing Switzerland, 2016., str. 31-51.

2. ĆURKOVIĆ, M., Ugovor o osiguranju osoba, život-nezgoda-zdravstveno, Inženjerski biro, Zagreb, 2009.

3. DAMM, R., Gendiagnostik als Gesetzgebungsprojekt. Regelungsinitiativen und Regelungsschwerpunkte, Bundesgesundheitsblatt Gesundheitsforschung Gesundhetisschutz, vol. 50, br. 2., 2007., str. 145-156.

4. DEUTSCHER BUNDESTAG, Zukunftsreport Individualisierte Medizin und Gesundheitssystem, FEUERSTEIN, G., KOLLEK, R., UHLEMANN, T., Gentechnik und Krankenversicherung: Neue Leistungsangebote im Gesundheitssystem. Nomos, Baden-Baden, 2002.

5. HANDSCHIN, CH., MEYER URA: A, Warum reagiert mein Patient anders auf dieses Medikament?, Schweiz Med Forum, vol. 12, br. 22, 2012., str. 425-433.

6. HOOD, L., FRIEND, SH, Predictive, personalized, preventive, participatory P4 cancer medicine, Nat Rev Clin Oncol, vol. 8, br. 3, 2011., str. 184-187.

7. KROEMER, H. K., Personalisierte Medizin - zum Stand der Forschung. In: PersonalisierteMedizin - der Patient als NutznieBer oder Opfer, Tagungsdokumentation, Jahrestagung des Deutschen Ethikrates, 2012, str. 11-21.

8. LI, Chumei, Clinical Genetics, vol. 79, br. 5, 2011., str. 403-412.

9. MIRNEZAMI, R., NICHOLSON, J., DARZI, A., Preparing for precision medicine, N Engl J Med 366(6), 2012., str. 489-491.

10. NIEDERLAG, W., LERNKE, H. U., RIENHOFF, O., Personalisierte Medizin und individuelle Gesundheitsversorgung, Bundesgesundheitsbl, vol. 53, 2010., str. 776-782.

11. PAK, J., Pravo osiguranja, Univerzitet Singidunum, Beograd, 2011.

12. PAVELIĆ, K., KRALJEVIĆ PAVELIĆ, S., SEDIĆ, M., Personalized Medicine: The Path to New Medicine, Personalized Medicine - A New Medical and Social Challenge, BODIROGA-VUKOBRAT, N., RUKAVINA, D., PAVELIĆ, K., SANDER, G. G., (ed.), Springer, 2016., str. 1-19.

13. SIMMONS LA, DINAN MA, ROBINSON TJ et al., Personalized medicine is more than genomic medicine: confusion over terminology impedes progress towards personalized health care, Pers Med, vol. 9, br. 1, 2012., str. 85-91.

14. SLAVNIĆ, J., Ugovor o dobrovoljnom zdravstvenom osiguranju kao predmet zakonskog regulisanja - prilog raspravi o regulisanju ugovora o osiguranju u novom Građanskom zakoniku Srbije, Zbornik radova "Evropske (EU) reforme u pravu osiguranja Srbije", Palić, 2010.

15. Stellungnahme zum Entwurf eines Gesetzes über die genetische Untersuchungen bei Menschen (Gendiagnostikgesetz - GenDG) vom, 13. Oktober 2008.,datum: 14. Januar 2009., Verband der Privaten Krankenversicherung e.V. [Mišljenje o Nacrtu Zakona o genskoj dijagnostici, od 13.10.2008, s datumom od 14. siječnja 2009., Udruga privatnih zdravstvenih osiguratelja].

16. TAUPITZ, J., PÖLZELBAUER C., Das deutsche Gendiagnostikgesetz, Arztrecht, br. 6, 2010., str. 144-149.

17. TRUSHEIM, MR., BERNDT, ER., DOUGLAS, FR., Stratified Medicine: strategic and economic implications of combining drugs and clinical biomarkers, Nat Rev Drug Discov, 2007, vol. 6, br. 4, 2007., str. 287-293. 
18. U.S. Department of Health and Human Services, U.S. Food and Drug Administration, 2013, Paving the way for personalized medicine:FDA's role in a new era of medical product development. http//www.fda.gov/downloads/ScienceResearch/SpecialTopics/ PersonalizedMedicine/UCM372421.pdf, pristupljeno, 15.10.2017.

19. VOGENBERG, F. R., ISAACSON BARASH ,C., PURSEL, M., Personalized medicine, Part 3: Challenges facing health care plans in implementing coverage polieies for pharmacogenomics and genetic testing, P T, vol. 35, br. 12, 2010., str. 670-675.

20. ZHENG, S., The Loopholes in the Law Prohibiting Genetic Discrimination, https:// www.theatlantic.com/health/archive/2017/03/genetic-discrimination-law-gina/519216/ (4. siječnja 2018.).

Pravni izvori

Hrvatska

1. Zakon o obveznim odnosima, Narodne novine, br. 35/05, 41/08, 125/11 i 78/15.

Njemačka

2. Gesetz über genetische Untersuchungen bei Menschen (GenDG), [Zakon o genskoj dijagnostici od 31. srpnja 2009. (BGB1. I S. 2529, 3672), zadnje mijenjan člankom 2 stavkom 1 Zakona od 4. studenog 2016. (BGB1. I S. 2460).].

3. Versicherungsvertragsgesetz (VVG), [ Zakon o ugovoru o osiguraju, od 23. studenog 2007. (BGBl. I S. 2631), zadnje mijenjan člankom 15 Zakona od 17. kolovoza 2017 (BGBl. I S. 3214).].

$S A D$

4. The Genetic Information Nondiscrimination Act of 2008, (GINA) Pub. L. 110-233,122 Stat. 881, od 21. svibnja 2008. [puni naziv: An Act to prohibit discrimination on the basis of genetic information with respect to health insurance and employment - Zakon o zabrani diskriminacije na temelju genetskih informacija u pogledu zdravstvenog osiguranja i zapošljavanja].

\section{Velika Britanija}

5. Concordat and Moratorium on Genetics and Insurance, [Konkordat i moratorij o genetici i osiguranju], Dostupno na: https://www.gov.uk/government/uploads/system/ uploads/attachment_data/file/390174/Genetics and Insurance guidance_2014.pdf (2. siječnja 2018.) 
Nada Bodiroga-Vukobrat*

Loris Belanić**

Summary

\section{INSURED RISK IN HEALTH INSURANCE IN LIGHT OF NEW DISCOVERIES IN THE FIELD OF GENETICS}

The paper provides an analysis of insured risk in health insurance in light of new discoveries in the field of genetics.

To begin with, the authors analyse the notion and the objective of personalized medicine; furthermore, they look into the significance of personalized medicine for risk coverage in private health insurance as well as into the issues regarding the relationship between personalized medicine and individualized insurance risk.

Comparative legal analyses of information and data protection in German, British and US laws makes a special part of the paper, where positive legal solutions are thoroughly analysed and critically reviewed.

The authors analyse positive legal solutions in Croatian law and give their proposals de lege ferenda because it is a sensitive area not yet regulated in the Republic of Croatia.

Keywords: insured risk, genetic information, health insurance, genetic testing data protection, predictive genetic testing, personalized medicine.

Zussamenfassung

\section{VERSICHERTES RISIKO IN DER KRANKENVERSICHERUNG IM LICHTE NEUER GENETISCHER ENTDECKUNGEN}

In der Arbeit wird das versicherte Risiko in der Krankenversicherung im Lichte neuer genetischer Entdeckungen analysiert.

Einleitend werden der Begriff und das Ziel der personalisierten Medizin analysiert. Anschließend betont man die Wichtigkeit der personalisierten Medizin für die Deckung von Risiken in der Privatversicherung sowie die Frage des Verhältnisses der personalisierten Medizin und Individualisierung versicherter Risiken.

* Nada Bodiroga-Vukobrat, Ph. D., Full Professor, Faculty of Law, University of Rijeka; nadab@ pravri.hr.

** Loris Belanić, Ph. D., Assistant Professor, Faculty of Law, University of Rijeka; lorisb@pravri. hr. 
Besonderen Wert legt man in der Arbeit auf die rechtsvergleichende Analyse des Daten- und Informationsschutzes im Recht von Deutschland, Großbritannien und der USA. Bei dieser Analyse werden positivrechtliche Beschlüsse kritisch besprochen.

Da dieser sensible Bereich in der Republik Kroatien nicht reguliert ist, werden kroatische positivrechtliche Beschlüsse analysiert und Vorschläge de lege ferenda gegeben.

Schlüsselwörter: versichertes Risiko, genetische Information, Krankenversicherung, Datenschutz bei genetischen Untersuchungen, prädiktive genetische Untersuchungen, personalisierte Medizin.

Riassunto

\section{IL RISCHIO ASSICURATO NELL'ASSICURAZIONE SANITARIA ALLA LUCE DELLE NUOVE SCOPERTE GENETICHE}

Nel lavoro si analizza il rischio assicurato nell'assicurazione sanitaria alla luce delle nuove scoperte genetiche.

Nella parte introduttiva del lavoro gli autori disaminano la nozione e lo scopo della medicina personalizzata, discernendo all'uopo il significato della medicina personalizzata per la copertura del rischio nell'assicurazione privata e distinguendo le questioni relative al rapporto tra medicina personalizzata ed individualizzazione del rischio nell'assicurazione.

Una parte specifica del contributo viene dedicata all'analisi comparata della tutela delle informazioni e dei dati nel diritto tedesco, nel diritto inglese ed in quello statunitense. Si individuano le rispettive soluzioni di diritto positivo e si offre una riflessione critica sulle medesime.

Gli autori analizzano le soluzioni di diritto positivo croate ed offrono proposte de lege ferenda, posto che tale delicata questione non trova regolamentazione nella Repubblica di Croazia.

Parole chiave: il rischio assicurato, informazione genetica, assicurazione sanitaria, tutela dei dati derivanti da prove genetiche, prove genetiche predittive, medicina personalizzata. 